\title{
PEMAKAIAN ABU AMPAS TEBU DENGAN VARIASI SUHU SEBAGAI SUBSTITUSI PARSIAL SEMEN DALAM CAMPURAN BETON
}

\author{
The Use Of Bagasse Ash With Temperature Variations \\ As A Partial Substitution Of Cement In The Concrete Mix \\ Rofikotul Karimah ${ }^{1} \&$ Yusuf Wahyudi ${ }^{2}$ \\ ${ }^{1 \& 2}$ Jurusan Teknik Sipil - Fakultas Teknik Univ. Muhammadiyah Malang \\ J1. Raya Tlogomas No. 246 Malang 65144 \\ Email: roikatulkarimah@gmail.com
}

\begin{abstract}
Bagasse is natural resource that has not been maximally used. The bagasse cinders, waste of burning was taken from Kebon Agung sugar mill, Malang, contains 38,09\% amount of silica. The research toward bagasse cinder is done by reburning it from temperature $400^{\circ} \mathrm{C}, 500^{\circ} \mathrm{C}, 600^{\circ} \mathrm{C}$, $700^{\circ} \mathrm{C}$ and $800^{\circ} \mathrm{C}$ with silica amount $49,60 \%, 52,59 \%, 53,92 \%, 54,46 \%$ and $54,96 \%$. Based on the research result was obtained the best press power in 28 days old is bagasse cinder which is burnt in $400^{\circ} \mathrm{C}$ of temperature by $5 \%$ precentage is 24,616 Mpa. The more high burning temperature, the lower of streng that is produced. The maximum water absorption value is in a mixed-bagasse cinder that is burnt in $800^{\circ} \mathrm{C}$ of temperature is $1,061 \%$. The proportion of correlation between streng and water disorption toward mixed bagasse cinder concrete is reverse. It is because of compound establisthhment of $\mathrm{Ca}(\mathrm{OH})_{2}$ with $\mathrm{SiO}_{2}$ is not happened yet perfectly, portlandid fase is still exist. Consequently, the expected cinder did not exist as changer role for repairing cement feature, on the contrary, it had filler role the same as sand.
\end{abstract}

Keywords: bagasse cinder, strength, absorption.

\begin{abstract}
Abstrak
Ampas tebu merupakan sumber daya alam yang masih belum maksimal pemanfaatannya. Limbah abu ampas tebu hasil sisa pembakaran yang didapat dari pabrik gula Kebon Agung, Malang memiliki kandungan silika sebesar 38,09\%. Penelitian terhadap abu ampas tebu dilakukan dengan melakukan pembakaran ulang dari suhu $400^{\circ} \mathrm{C}, 500^{\circ} \mathrm{C}, 600^{\circ} \mathrm{C}, 700^{\circ} \mathrm{C}$, dan $800^{\circ} \mathrm{C}$ dengan nilai silika yang didapat sebesar 49,60\%, 52,59\%, 53,92\%, 54,46\%, dan 54,96\%. Berdasarkan hasil penelitian diperoleh kekuatan tekan yang paling baik pada umur 28 hari adalah abu ampas tebu yang dibakar pada suhu $400^{\circ} \mathrm{C}$ dengan persentase 5\% sebesar 24,616 Mpa. Semakin tinggi suhu pembakaran kuat tekan yang dihasilkan semakin menurun. Nilai penyerapan air maksimum terdapat pada campuran abu ampas tebu yang di bakar pada suhu $800^{\circ} \mathrm{C}$ yakni sebesar $1,061 \%$. Hubungan antara kuat tekan dan penyerapan air pada campuran beton abu ampas tebu berbanding terbalik. Hal tersebut terjadi karena pembentukan senyawa $\mathrm{Ca}(\mathrm{OH})_{2}$ dengan $\mathrm{SiO}_{2}$ belum terjadi secara sempurna, fase portlandidnya masih ada. Akhirnya abu yang dikehendaki tidak bertindak sebagai pengganti untuk memperbaiki sifat semen melainkan bertindak sebagai filler sama seperti pasir.
\end{abstract}

Kata Kunci : abu ampas tebu, kuat tekan, absorbsi.

\section{PENDAHULUAN}

PT. PG Kebon Agung Malang merupakan pabrik gula yang menghasilkan limbah ampas tebu sebesar 32\% dari tebu giling,limbah yang dihasilkan hanya dihampar dipekarangan dan tidak dimanfaatkan sehingga dapat mencemari udara karena ukurannya yang halus dan mudah berterbangan. sebagai pertimbangan digunakannya abu ampas tebu (AAT) pada penelitian disebabkan karena pengadaannya cukup mudah dan murah sehingga bila ditinjau dari segi ekonomis akan lebih menguntungkan. AAT yang diperoleh dari sisa pembakaran pabrik gula juga memiliki kandungan silikat ( $\mathrm{SiO} 2$ ), aluminat (Al2O3), Ferrit (Fe2O3) yang merupakan bahan utama untuk pembentuk semen portland dan termasuk sebagai pozzolan. 
Penelitian tentang pemanfaatan AAT telah dilakukan oleh Rompas, dkk (2013) yang hasilnya menunjukkan bahwa AAT yang dibakar kembali pada suhu pembakaran 600 0C menghasilkan kuat tekan terbesar dicapai pada kadar AAT sebanyak 5\% . Namun demikian perlu dilakukan penelitian lanjutan mengenai variasi suhu pembakaran AAT $(400,500,600,700,800) 0 \mathrm{C}$ untuk mendapatkan nilai kuat tekan dan berat jenis beton maksimum dengan substitusi kadar abu ampas tebu sebanyak 5\%. Penggunaan pozzolan pada campuran beton selain dapat mengikat $\mathrm{Ca}(\mathrm{OH}) 2$ menjadi $\mathrm{CSH}$ pada proses hidrasi antara air dan semen, juga dapat mengurangi panas hidrasi karena reaksi pozzolan yang cukup lambat. Hal ini menyebabkan dapat mengurangi retak-retak pada beton, sehingga beton akan lebih tahan terhadap serangan zat-zat agresif. Pembentukan CSH oleh pozzolan juga akan mengakibatkan tertutupnya pori-pori pada beton, sehingga beton akan lebih kedap, dengan demikian ion sulfat tidak mudah menembus lapisan beton.

Penelitian yang dilakukan oleh Nurwaji Wibowo (2006), diketahui ampas tebu apabila dibakar pada suhu $600^{\circ} \mathrm{C}$ berhasil menaikkan unsur silika ( $\mathrm{SiO} 2)$, aluminat (Al2O3), ferrit (Fe2O3) sebesar 77,33\% dan memenuhi syarat sebagai pozzolan. Penelitian tentang pemanfaatan AAT juga telah dilakukan oleh Rompas, dkk (2013) yang hasilnya menunjukkan bahwa AAT yang dibakar kembali pada suhu pembakaran 600 0C menghasilkan kuat tekan terbesar dicapai pada

kadar AAT sebanyak 5\% . Namun demikian perlu dilakukan penelitian lanjutan mengenai variasi suhu pembakaran AAT $(400,500,600,700,800) 0 \mathrm{C}$ untuk mendapatkan nilai kuat tekan dan absorsi beton maksimum dengan substitusi kadar abu ampas tebu sebanyak 5\% dari berat semen untuk masing-masing variasi suhu pembakaran sesuai rencana campuran beton.

\section{METODE PENELITIAN}

Penelitian ini pada prinsipnya dilakukan tiga tahap. Tahap pertama adalah tahap persiapan diawali dengan pengadaan semen,kerikil, pasir, air dan abu ampas tebu. Abu ampas tebu yang digunakan adalah hasil variasi pembakaran yang dilakukan di pabrik keramik Dinoyo. Kemudian dilanjutkan dengan pemeriksaan sifat fisik dan kimia abu ampas tebu. Karena sifat fisik abu ampas tebu yang hampir menyerupai semen maka untuk pemeriksaan materialnya diperlakukan sama seperti pemeriksaan semen. Tahap kedua adalah tahap pelaksanaan penelitian dengan penyusunan mix design,pencampuran dan pembuatan benda uji silinder beton. Jumlah benda uji yang digunakan dalam penelitian ini adalah 60 buah silinder berukuran $15 \times 30 \mathrm{~cm}$ dengan masing-masing variasi suhu abu ampas tebu sebesar $(400,500,600,700,800) 0 \mathrm{C}$. Tahap ketiga adalah tahap pengujian absorsi beton dan kuat tekan (SNI 03-1974-1990). Adapun tahapan penelitian yang dilakukan, dijelaskan pada gambar 1.

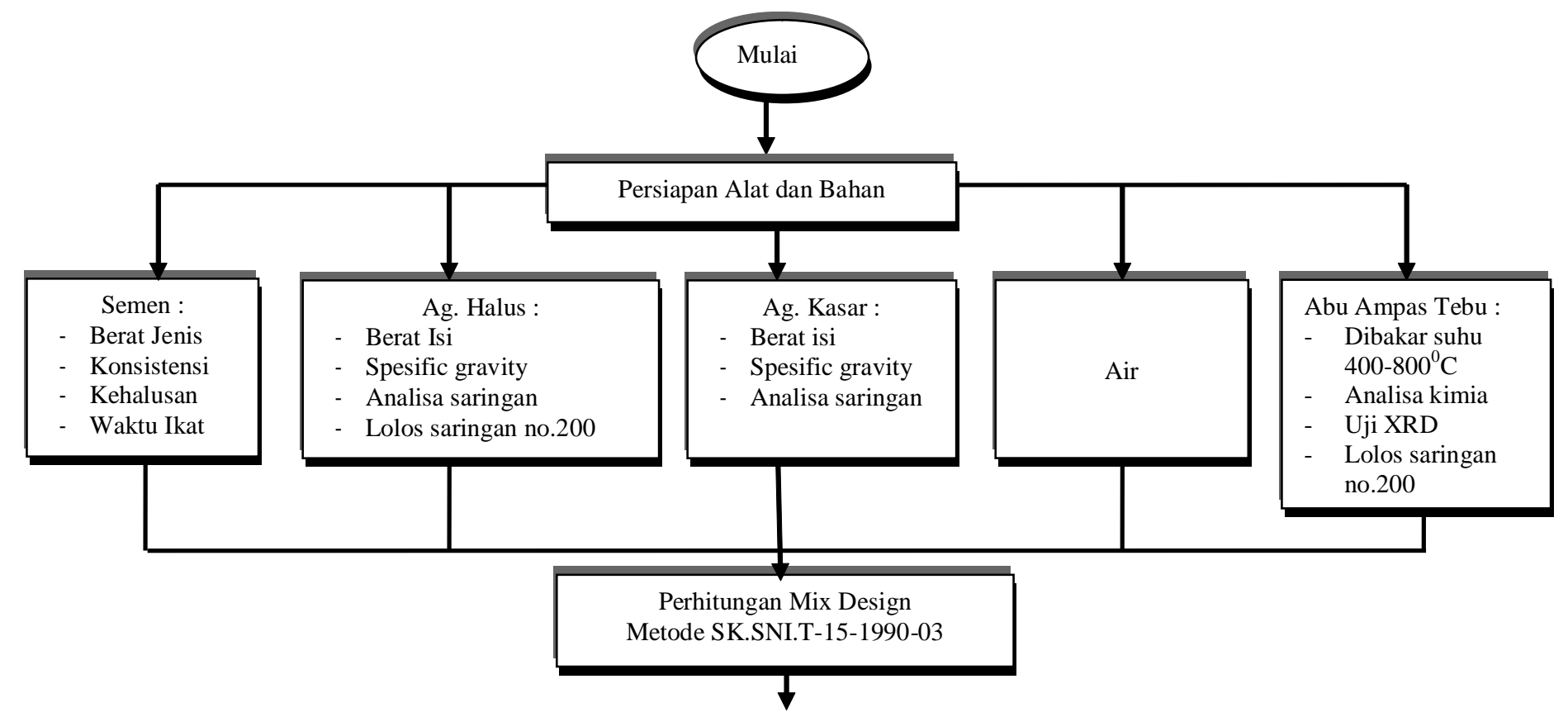




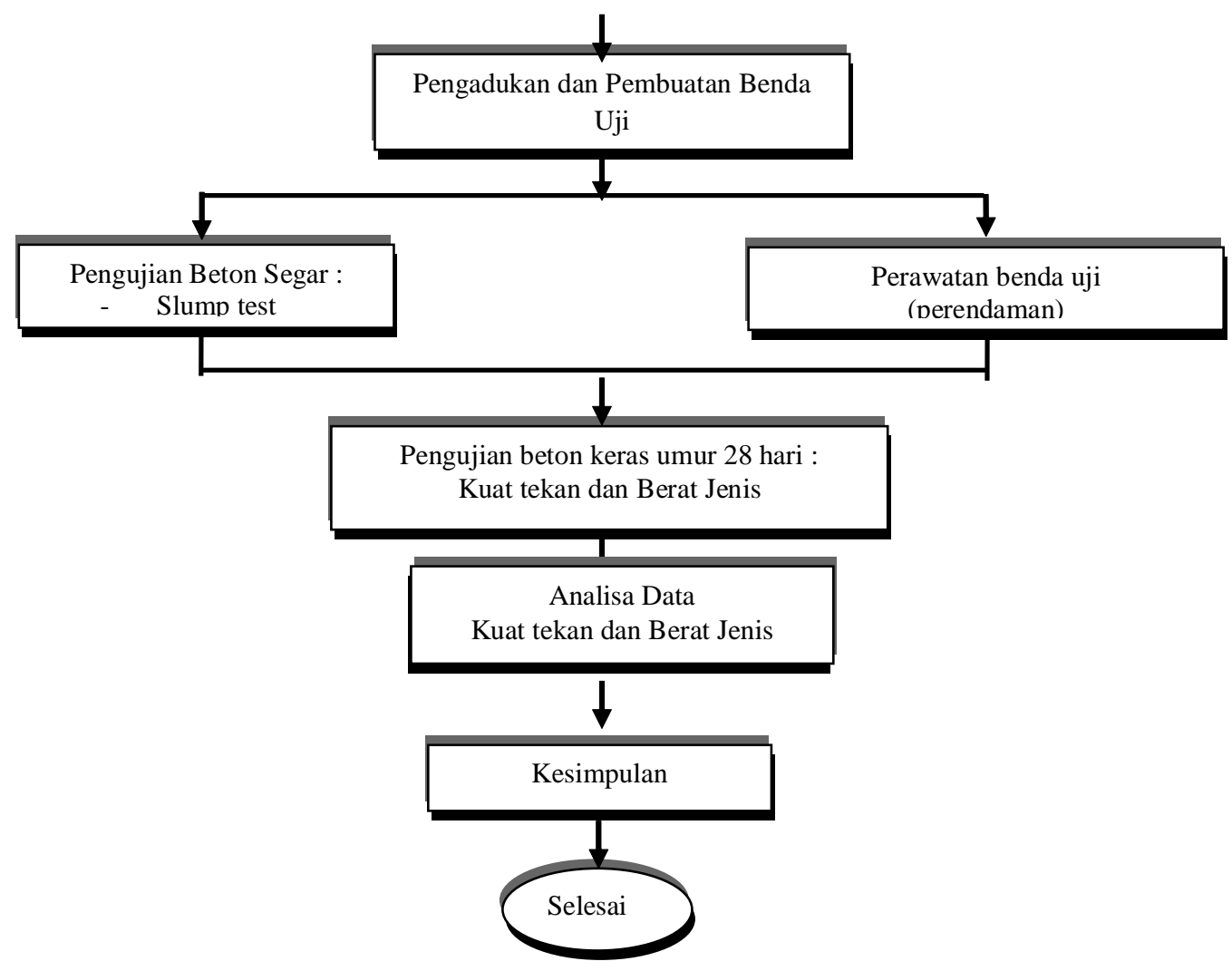

Gambar 1. Bagan Alir Penelitian

HASIL DAN PEMBAHASAN

Hasil Pemeriksaan Bahan

Semen

Tabel 1. Hasil Pemeriksaan Semen

\begin{tabular}{lccc}
\hline \multicolumn{1}{c}{$\begin{array}{c}\text { Jenis } \\
\text { Pemeriksaan }\end{array}$} & Standar & Hasil Pengujian & Syarat \\
\hline Berat jenis & ASTM C-188144 & $3,15 \mathrm{gr} / \mathrm{cm}^{3}$ & $3,15-3,17 \mathrm{gr} / \mathrm{cm}^{3}$ \\
Kehalusan & ASTM C-134-66 & $4,50 \%$ & $<10 \%$ diatas saringan 200 \\
Konsistensi & ASTM C-187-71 & $24,30 \%$ & - \\
Waktu ikat awal & ASTM C-191-71 & 130 menit & Lebih dari 60 menit \\
Waktu ikat akhir & ASTM C-191-71 & 175 menit & Kurang dari 8 jam \\
\hline
\end{tabular}

\section{Pasir (Agregat Halus)}

Tabel.2. Hasil Pemeriksaan Pasir Alam

\begin{tabular}{lccc}
\hline \multicolumn{1}{c}{$\begin{array}{c}\text { Jenis } \\
\text { Pemeriksaan }\end{array}$} & Standar & $\begin{array}{c}\text { Hasil } \\
\text { Pengujian }\end{array}$ & Syarat \\
\hline Bahan lewat saringan & ASTM C-117 & $2,10 \%$ & Kurang dari 5\% \\
200 & & Daerah gradasi I & - \\
Analisa saringan & ASTM C-136-46 & FM $=3,01$ & $1,5-3,8$ \\
Berat jenis & PB - 0203 - 76 & $2,74 \mathrm{gr} / \mathrm{cm}^{3}$ & $2,4-2,9 \mathrm{gr} / \mathrm{cm}^{3}$ \\
Absorbsi & ASTM C-128-68 & $1,42 \%$ & $3 \%$ \\
\hline
\end{tabular}




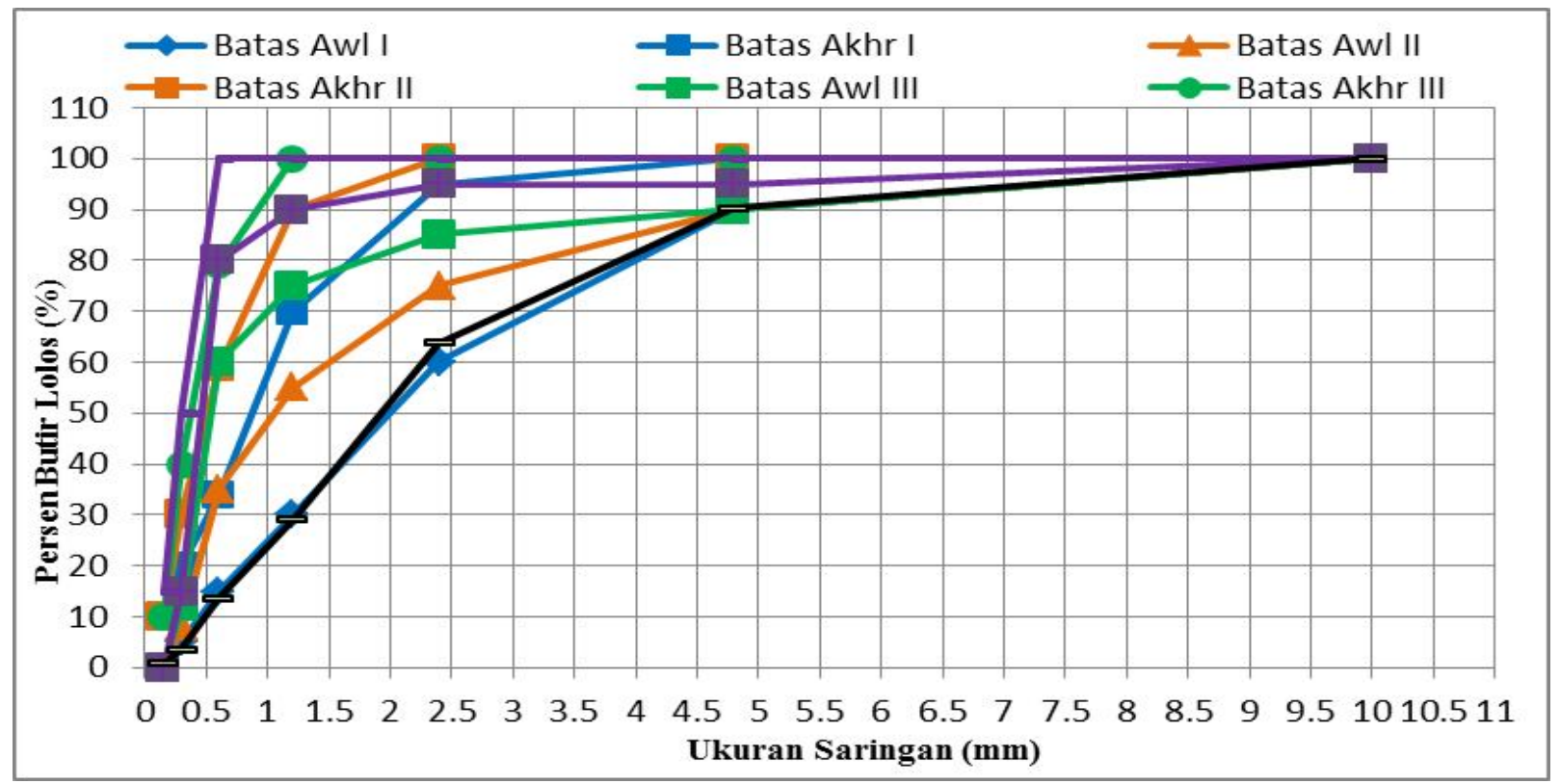

Gambar 2. Grafik Gradasi Agregat Halus

Dari semua hasil pemeriksaan material alam ini masuk daerah gradasi I dan memenuhi agregat halus tersebut dapat dikatakan bahwa pasir syarat sebagai bahan campuran beton.

\section{Kerikil (Agregat Kasar )}

Tabel 3. Hasil Pemeriksaan Agregat Kasar

\begin{tabular}{|c|c|c|c|}
\hline $\begin{array}{c}\text { Jenis } \\
\text { Pemeriksaan } \\
\end{array}$ & Standar & $\begin{array}{c}\text { Hasil } \\
\text { Pengujian }\end{array}$ & Syarat \\
\hline \multirow{2}{*}{ Analisa saringan } & \multirow{2}{*}{ ASTM C-136-46 } & $\begin{array}{c}\text { Besar butir max } 20 \\
\mathrm{~mm}\end{array}$ & \\
\hline & & $\mathrm{FM}=5,18$ & $5-7$ \\
\hline Berat jenis & ASTM C- $128-68$ & 2,62 ton $/ \mathrm{m}^{3}$ & $2,50-2,70$ ton $/ \mathrm{m}^{3}$ \\
\hline Absorpsi & ASTM C- $128-68$ & $1,18 \%$ & Kurang dari $3 \%$ \\
\hline Abrasi (Keausan) & ASTM C - 131 & $13,72 \%$ & $\operatorname{Max} 45 \%$ \\
\hline
\end{tabular}

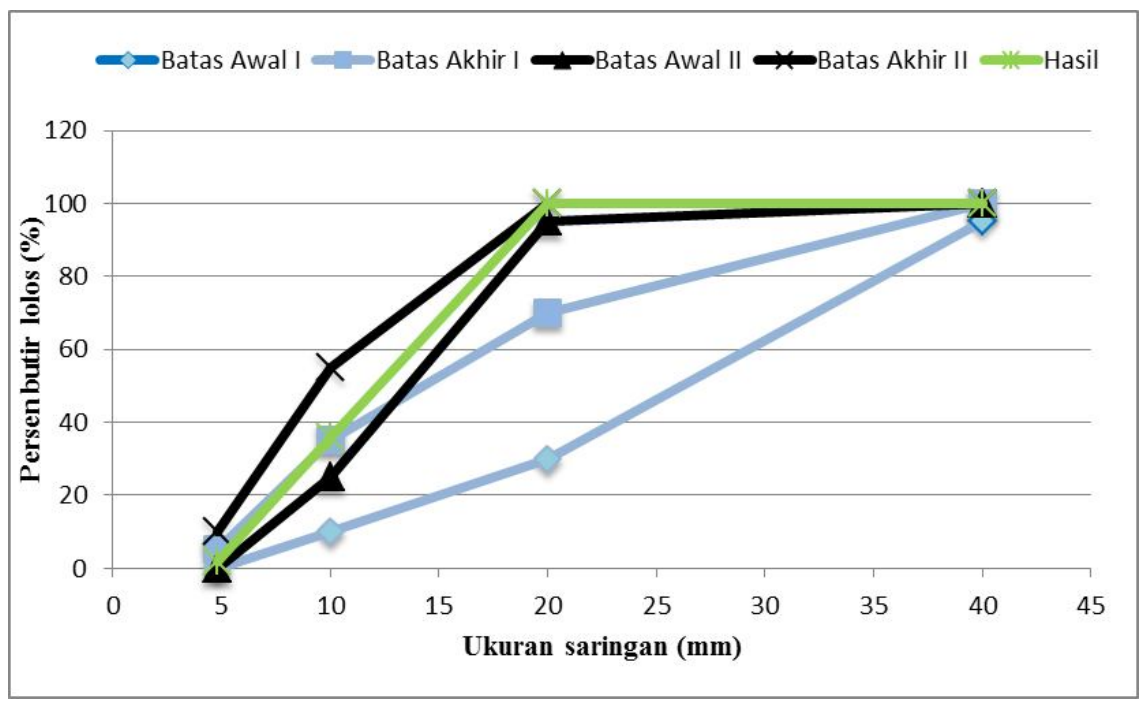

Gambar 3. Grafik Gradasi Agregat Kasar 
Dari semua hasil pemeriksan material, agregat kasar tersebut masuk daerah gradasi II dan memenuhi syarat sebagai bahan campuran beton.

\section{Abu Ampas Tebu}

Tabel 4. Hasil Pengujian Komposisi Kimia Abu Ampas Tebu

\begin{tabular}{lcccccc}
\hline \multirow{2}{*}{ Unsur/senyawa yang diuji } & \multicolumn{5}{c}{ Hasil Pengujian Komposisi Kimia Abu Ampas Tebu untuk } \\
& \multicolumn{5}{c}{ Masing-masing Suhu (\%) } \\
\cline { 2 - 7 } & Normal & $\mathbf{4 0 0}^{\mathbf{0}} \mathbf{C}$ & $\mathbf{5 0 0}^{\mathbf{0}} \mathbf{C}$ & $\mathbf{6 0 0}^{\mathbf{0}} \mathbf{C}$ & $\mathbf{7 0 0}^{\mathbf{0}} \mathbf{C}$ & $\mathbf{8 0 0}^{\mathbf{0}} \mathbf{C}$ \\
\hline \multirow{2}{*}{ Silikat $\left(\mathrm{SiO}_{2}\right)$} & 38,09 & 49,60 & 52,59 & 53,92 & 54,46 & 54,96 \\
Besi Oksida $\left(\mathrm{Fe}_{2} \mathrm{O}_{3}\right)$ & 8,92 & 16,37 & 18,36 & 19,14 & 22,19 & 24,43 \\
Alumunium $\left.\mathrm{Oksida}_{(\mathrm{Al}} \mathrm{O} \mathrm{O}\right)$ & 5,47 & 11,26 & 13,76 & 15,31 & 14,25 & 14,74 \\
& $\mathbf{5 2 , 4 8}$ & $\mathbf{7 7 , 2 4}$ & $\mathbf{8 4 , 7 1}$ & $\mathbf{8 8 , 3 7}$ & $\mathbf{9 0 , 9 0}$ & $\mathbf{9 4 , 1 3}$ \\
\hline
\end{tabular}

Dari hasil pengujian komposisi kimia abu ampas tebu terlihat bahwa unsur silikat $\left(\mathrm{SiO}_{2}\right)$ merupakan unsur yang paling dominan, sehingga bahan dasar limbah penggilingan tebu dapat digunakan sebagai bahan pengganti sebagian semen, dimana menurut
ASTM C 618-86 pozzolan memiliki mutu yang baik apabila jumlah kadar $\mathrm{SiO}_{2}+\mathrm{Al}_{2} \mathrm{O}_{3}+\mathrm{Fe}_{2} \mathrm{O}_{3}$ tinggi dan reaktifitasnya tinggi dengan kapur. Komposisi kimia abu ampas tebu tersebut masuk kriteria pozzolan yang distandarkan oleh ASTM C 618-86.

Tabel 5. Hasil Pemeriksaan Abu Ampas Tebu

\begin{tabular}{lrrrrr}
\hline \multirow{2}{*}{ Jenis Pemeriksaan } & \multicolumn{5}{c}{ Hasil Pemeriksaan } \\
& $\mathbf{4 0 0}^{\mathbf{}} \mathbf{C}$ & $\mathbf{5 0 0}^{\mathbf{0}} \mathbf{C}$ & $\mathbf{6 0 0}^{\mathbf{0}} \mathbf{C}$ & $\mathbf{7 0 0}^{\mathbf{}} \mathbf{C}$ & $\mathbf{8 0 0}^{\mathbf{0}} \mathbf{C}$ \\
\hline Berat Jenis gr/cm & 2,012 & 2,023 & 2,099 & 2,129 & 2,141 \\
Kehalusan (\%) & 3,34 & 3,4 & 2,13 & 4,2 & 3,01 \\
Konsistensi (\%) & 26,4 & 27,3 & 27 & 27 & 27,2 \\
Waktu Ikat Awal (menit) & 147 & 174 & 159 & 156 & 168 \\
Waktu Ikat Akhir (menit) & 195 & 240 & 225 & 225 & 225 \\
\hline
\end{tabular}

\section{Hasil Analisis XRD (X-Ray Diffraction)}

Abu ampas tebu hasil limbah pabrik gula Kebon Agung, Malang diabukan dalam tungku pembakaran keramik pada suhu $400^{\circ} \mathrm{C}, 500^{\circ} \mathrm{C}, 600^{\circ} \mathrm{C}, 700^{\circ} \mathrm{C}$ dan $800^{\circ} \mathrm{C}$ selama 1 jam. Abu ampas tebu yang dihasilkan diayak lolos saringan no. 200, hasil ayakan di uji bentuk kekristalan dan amorf abu dengan menggunakan metode XRD.

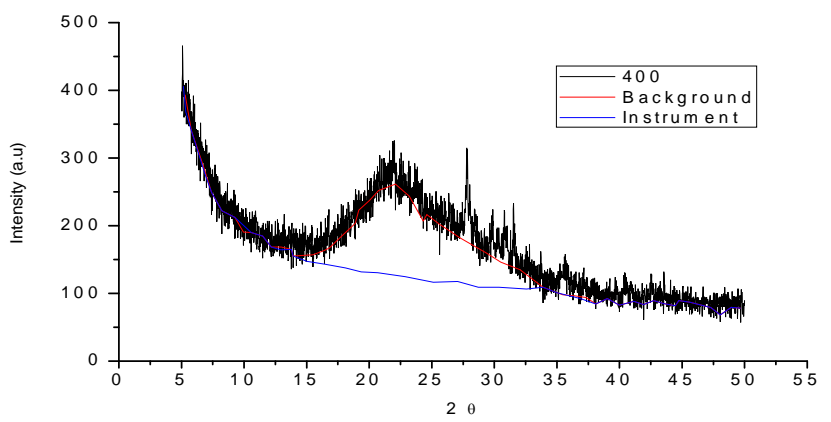

Gambar 4. XRD abu ampas tebu pada suhu pembakaran $400^{\circ} \mathrm{C}$

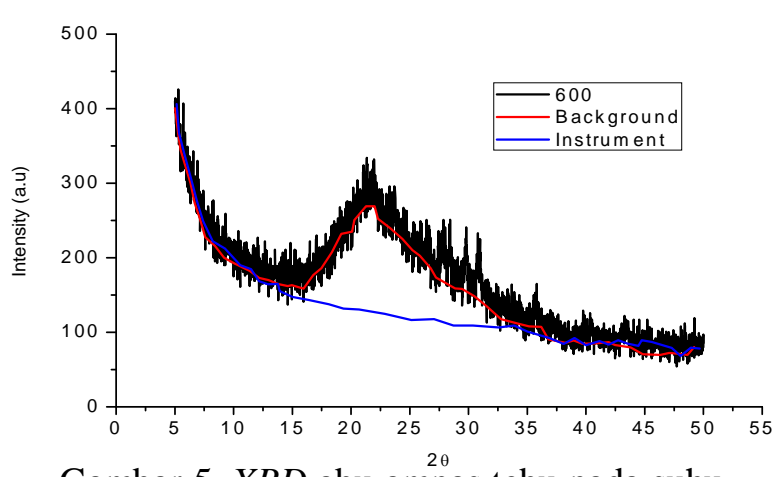

Gambar 5. XRD abu ampas tebu pada suhu

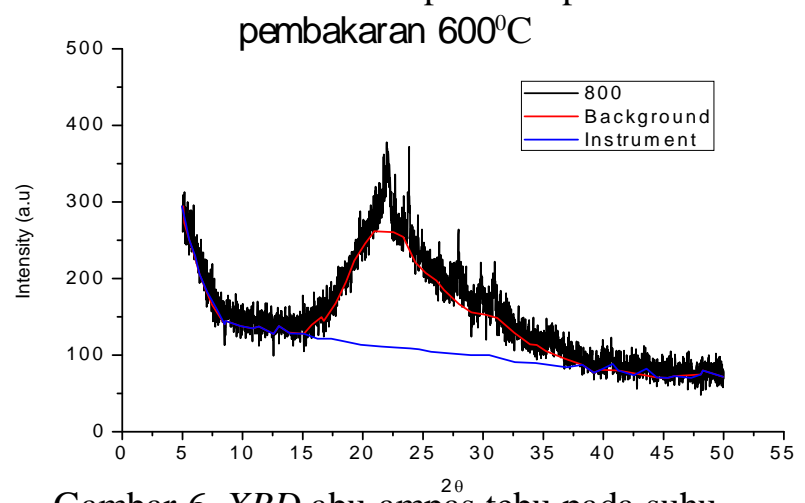

Gambar 6. $X R D$ abu ampas tebu pada suhu pembakaran $800^{\circ} \mathrm{C}$ 
Berikut perhitungan phasa kristalin dan amorfus abu ampas tebu :

Tabel 6. Hasil Perhitungan Integral Abu Ampas Tebu

\begin{tabular}{cccc}
\hline $\begin{array}{c}\text { Sampel } \\
\text { Abu }\end{array}$ & Total & $\begin{array}{c}\text { Luas Area Phasa } \\
\text { Background }\end{array}$ & Instrumen \\
\hline 400 & 7715 & 7022 & 5819 \\
600 & 7703 & 7041 & 5819 \\
800 & 6977 & 6401 & 4902 \\
\hline
\end{tabular}

Tabel 7. Hasil Perhitungan Phasa Kristalin Abu Ampas Tebu

\begin{tabular}{cccc}
\hline $\begin{array}{c}\text { Sampel } \\
\text { Abu }\end{array}$ & \multicolumn{2}{c}{ Luas Area Phasa } & Kristalinitas \\
Kristalin & Amorph & $\mathbf{( \% )}$ \\
\hline 400 & 693 & 1203 & 36,6 \\
600 & 662 & 1222 & 35,1 \\
800 & 576 & 1499 & 27,7 \\
\hline
\end{tabular}

Hasil pengujian tersebut menunjukkan bahwa kandungan silika dalam abu ampas tebu sebagian besar bersifat amorf, terlihat pada grafik tersebut semakin tinggi suhu pembakarn maka silika amorf yang dihasilkan semakin baik, kekristalannya semakin berkurang. Hal ini memperlihatkan bahwa terdapat dalam jumlah yang sangat kecil difraksi gelombang sinar-X berpuncak tajam dan bersudut, hal ini menunjukkan bahwajumlah $\mathrm{SiO}_{2}$ kristlain juga semakin kecil. Dengan demikian maka sebagian besar $\mathrm{SiO}_{2}$ dalam abu ampas tebu bersifat amorf.

\section{Hasil Pemeriksaan Benda Uji (Silinder)} Kuat Tekan Beton

Tabel 8. Hasil Uji Kuat Tekan Beton

\begin{tabular}{ccccccc}
\hline Kode & $\begin{array}{c}\text { Luas } \\
\left(\mathbf{m m}^{2}\right)\end{array}$ & $\begin{array}{c}\text { Dial } \\
\text { Beban } \\
(\mathbf{k N})\end{array}$ & $\begin{array}{c}\text { Beban } \\
\text { Max }(\mathbf{N})\end{array}$ & $\begin{array}{c}\text { Kuat } \\
\text { Tekan } \\
(\mathbf{M p a})\end{array}$ & $\begin{array}{c}\text { Kuat } \\
\text { tkan rata- } \\
\text { rata (Mpa) }\end{array}$ & $\begin{array}{c}\text { Persentasi } \\
\text { Kenaikan } \\
(\boldsymbol{\%})\end{array}$ \\
\hline BN A & 17671,46 & 450 & 450000 & 25,465 & & \\
BN B & 17671,46 & 465 & 465000 & 26,314 & 25,370 & 0,000 \\
BN C & 17671,46 & 430 & 430000 & 24,333 & & \\
400 A & 17671,46 & 420 & 420000 & 23,767 & & \\
400 B & 17671,46 & 430 & 430000 & 24,333 & 24,616 & $-2,974$ \\
400 C & 17671,46 & 455 & 455000 & 25,748 & & \\
500 A & 17671,46 & 415 & 415000 & 23,484 & & \\
500 B & 17671,46 & 415 & 415000 & 23,484 & 23,673 & $-6,691$ \\
500 C & 17671,46 & 425 & 425000 & 24,050 & & \\
600 A & 17671,46 & 400 & 400000 & 22,635 & & $-7,807$ \\
600 C & 17671,46 & 430 & 430000 & 24,333 & 23,390 & \\
600 E & 17671,46 & 410 & 410000 & 23,201 & & $-8,922$ \\
700 F & 17671,46 & 415 & 415000 & 23,484 & & $-9,294$ \\
700 C & 17671,46 & 400 & 400000 & 22,635 & 23,107 & \\
700 A & 17671,46 & 410 & 410000 & 23,201 & & \\
800 A & 17671,46 & 405 & 405000 & 22,918 & & \\
800 F & 17671,46 & 415 & 415000 & 23,484 & 23,013 & \\
800 D & 17671,46 & 400 & 400000 & 22,635 & & \\
\hline & & & & & & \\
\hline
\end{tabular}




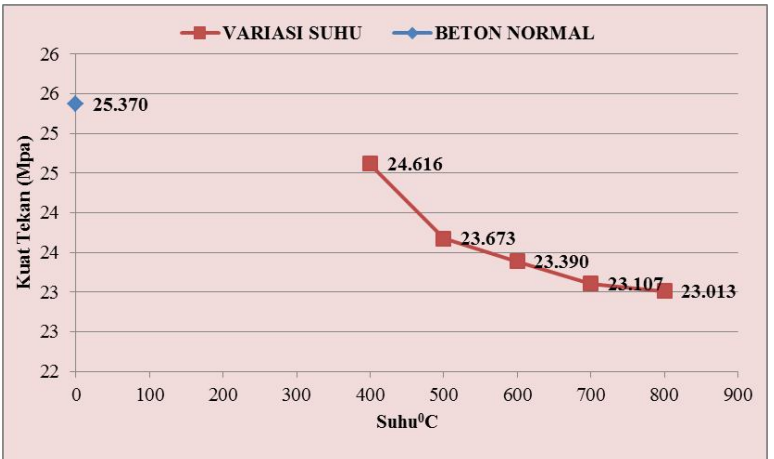

Gambar 9. Grafik Hasil Uji Absorbsi Beton

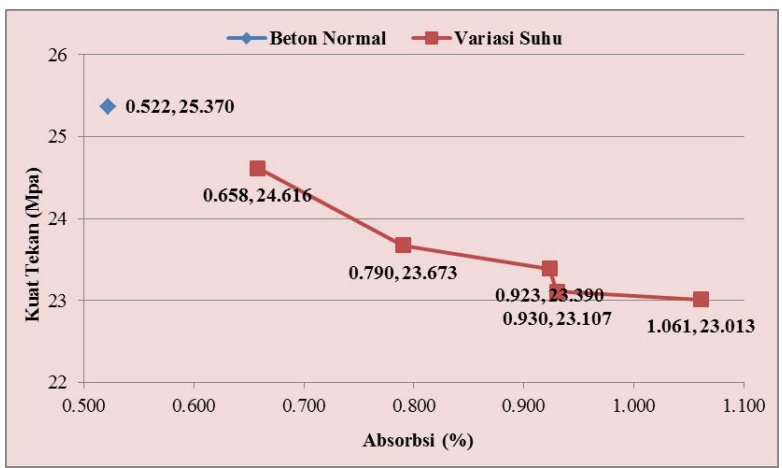

Gambar 10. Grafik Hubungan Antara Kuat Tekan dan Absorbsi

Nilai kuat tekan optimal tidak didapatkan dikarenakan semakin tinggi suhu pembakaran abu ampas tebu maka kuat tekannya semakin menurun. Didapat kuat tekan yang paling tinggi terdapat pada campuran beton normal yakni sebesar $25,370 \mathrm{Mpa}$ dan nilai kuat tekan terendah terdapat pada variasi suhu $800^{\circ} \mathrm{C}$ pembakaran abu ampas tebu sebesar 23,013 Mpa. Hal ini berbanding terbalik dengan kuat tekan, ketika nilai kuat tekan semakin menurun maka nilai penyerapan air (absorbsi) semakin meningkat. Nilai penyerapan air terendah terdapat pada campuran beton normal sebesar $0,522 \%$ dan penyerapan air tertinggi terdapat pada abu ampas tebu yang dibakar pada suhu $800^{\circ} \mathrm{C}$.

\section{KESIMPULAN DAN SARAN}

\section{Kesimpulan}

- Semakin tinggi suhu pembakaran abu ampas tebu (AAT) yang digunakan sebagai pengganti sebagian semen menyebabkan nilai kuat tekan beton mengalami penurunan, Penurunan kuat tekan disebabkan reaksi pozzolan $\left(\mathrm{SiO}_{2}\right)$ dengan $\mathrm{Ca}\left(\mathrm{OH}_{2}\right)$ belum terjadi secara sempurna pada umur 28 hari, sehingga kontribusinya terhadap kekuatan beton membutuhkan waktu yang lebih panjang.

- $\quad$ Suhu pembakaran abu ampas tebu (AAT) pada $400^{\circ} \mathrm{C}-800^{\circ} \mathrm{C}$ meningkatkan nilai absorbsi secara berturut-turut $0,522 \%, 0,658 \%$, $0,790 \%, 0,923 \%$, dan $1,061 \%$.

\section{Saran}

- Untuk penelitian dengan variasi suhu pembakaran lebih baik menggunakan sampel dalam bentuk ampas tebu, agar tercapai pengendalian suhu yang baik.

- Pada saat melakukan pengadukan dengan menggunakan molen, sebaiknya menyeragamkan waktu pemutaran pada setiap campuran beton.

\section{DAFTAR PUSTAKA}

Mulyono, Tri, 2004, Teknologi Beton, CV. Andi Offset, Yogyakarta.

Murdock, L.J. dan Brook, K.M., 1999, Bahan dan Praktek Beton; diterjemahkan oleh Ir. Stephanus Hendarko, Jakarta; Erlangga

Persyaratan Umum Bahan Bangunan di Indonesia (PUBI), 1982, Departemen Pekerjaan Umum, Direktorat Jendral Cipta Karya, Bandung

Suharlinah Lien, 2011 "Pemanfaatan Biopozzolan Eks Limbah Penggilingan Tebu Untuk Meningkatkan Mutu Beton" Pusat Penelitian dan Pengembangan Jalan dan Jembatan, Badan Penelitian dan Pengembangan, Departemen Pekerjaan Umum Republik Indonesia, Banten.

Siregar N, 2010 "Pemanfaatan Abu Pembakaran Ampas Tebu Pada Pembuatan Batu Bata" Skripsi Fakultas Matematika dan Ilmu Pengetahuan Alam, Universitas Sumatera Utara, Medan.

Tata Cara Perhitungan Struktur Beton Untuk Bangunan Gedung (SK SNI T-15-1991-03), Yayasan Lembaga Penyelidikan Masalah Bangunan: Jakarta.

Tjokrodimuljo,Kardiyono, 1992, Buku Ajar Teknologi Beton, Jurusan Teknik Sipil FakultasTeknik Universitas Gajah Mada, Yogyakarta. 